\title{
Development of a diagrammatic scale for the evaluation of postharvest physiological deterioration in cassava roots
}

\author{
Marcela Tonini Venturini(1), Leandro Ribeiro dos Santos ${ }^{(1)}$ and Eder Jorge de Oliveira(2)
}

(1)Universidade Federal do Recôncavo da Bahia, Rua Rui Barbosa, no 710, CEP 44380-000 Cruz das Almas, BA, Brazil. E-mail: cosalin2@yahoo.com.br, Iribeiro40@gmail.com (2)Embrapa Mandioca e Fruticultura, Rua da Embrapa, Caixa Postal 007, CEP 44380-000 Cruz das Almas, BA, Brazil. E-mail: eder.oliveira@embrapa.br

\begin{abstract}
The objective of this work was to develop a scale to assess the severity of postharvest physiological deterioration (PPD) of cassava roots, and to validate this scale for accuracy and reproducibility estimates. A diagrammatic scale (0 to $100 \%$ ) for the damaged roots was analyzed according to precision, accuracy, and reproducibility. Seven evaluators (four with experience and three without it) quantified the PPD severity, with or without the scale, considering 150 roots with different levels of PPD. Without and with the use of the scale, respectively, the inexperienced evaluators obtained coefficients of determination $\left(R^{2}\right)$ from 0.76 to 0.86 and 0.87 to 0.92 , and the experienced evaluators obtained $R^{2}$ from 0.90 to 0.96 and 0.96 to 0.97 . The values of the intercept (a) obtained by both the experienced and inexperienced evaluators who did not use the scale were all significant, while after using the scale, only two evaluators got values that were not significantly different from one. Evaluation reproducibility between the evaluators ranged from 0.61 to 0.91 for the inexperienced ones and from 0.83 to 0.95 for the experienced ones. The proposed diagrammatic scale was considered appropriate to estimate the severity of PPD in cassava roots, and can be used to identify sources of tolerance to postharvest deterioration.
\end{abstract}

Index terms: Manihot esculenta, physiological processes, shelf life, subsistence crop, tolerance.

\section{Desenvolvimento de escala diagramática para avaliação da deterioração fisiológica pós-colheita em mandioca}

Resumo - O objetivo deste trabalho foi desenvolver uma escala para avaliar a severidade da deterioração fisiológica pós-colheita (DFPC) da mandioca, e validar esta escala quanto a estimativas de acurácia e reprodutibilidade. Uma escala diagramática $(0$ a $100 \%)$ referente à área lesionada das raízes foi avaliada de acordo com sua precisão, acurácia e reprodutibilidade. Sete avaliadores (quatro experientes e três inexperientes) quantificaram a severidade da DFPC, com ou sem o uso da escala, tendo-se considerado 150 raízes com diferentes níveis de DFPC. Sem e com o uso da escala, respectivamente, os avaliadores inexperientes obtiveram coeficiente de determinação $\left(R^{2}\right)$ de 0,76 a 0,86 e de 0,87 a 0,92 , e os avaliadores experientes obtiveram $R^{2}$ de 0,90 a 0,96 e de 0,96 a 0,97 . Os valores do intercepto (a), obtidos tanto pelos avaliadores experientes como pelos inexperientes, sem uso da escala, foram significativos, enquanto, após o uso da escala, apenas dois avaliadores obtiveram valores que não foram significativamente diferentes de um. A reprodutibilidade das avaliações entre os avaliadores variou de 0,61 a 0,91 , para os inexperientes, e de 0,83 a 0,95 , para os experientes. A escala diagramática proposta foi considerada adequada para estimar a severidade da DFPC em raízes de mandioca e poderá ser utilizada para identificar fontes de tolerância à deterioração pós-colheita.

Termos para indexação: Manihot esculenta, processos fisiológicos, vida de prateleira, culturas de subsistência, tolerância.

\section{Introduction}

Cassava (Manihot esculenta Crantz) plays an important role in the global food diet because of its high energy content, ease of cultivation, relatively low incidence of pests and diseases, tolerance to drought and to acidic soils, and flexibility of harvesting, characterizing it as an important crop for food security in some countries (Sánchez et al., 2006). However, cassava roots have a short shelf life, due to a rapid process of postharvest physiological deterioration (PPD), which makes it unpalatable and commercially unfeasible 24 to 48 hours after harvesting (Sánchez et al., 2006; Morante et al., 2010). Besides, during 
this period, bluish or dark brown vascular streaking symptoms may occur (Salcedo \& Siritunga, 2011). Due to the high perishability of cassava root, caused by PPD, the economic losses are inevitable, negatively impacting the supply of roots as a raw material for fresh or industrial consumption. Losses caused by PPD may occur during various stages of the production chain, making it difficult to estimate the overall losses, although field observations indicate losses of more than $60 \%$ when roots have not been taken for processing three days after harvest.

The PPD processes involved the production of reactive oxygen species (ROS) related to the aerobic respiration. ROS is able to start the signal transduction cascades which activate defense-related gene expression and immediately cause cellular damage, by rapidly oxidizing cellular components (Zidenga et al., 2012).

In general, the primary measure to mitigate losses caused by PPD is the improve timing of the harvest, so that the roots are stored from field to commercialization. However, this process requires differentiated crop logistics by producers, which can make them more vulnerable to price fluctuations for cassava root. Other measures have been suggested, such as packing roots in plastic bags or subjecting them to cold storage and protecting the roots with paraffin wax (Cereda \& Vilpoux, 2003; Aristizábal \& Sánchez, 2007). Nevertheless, these strategies involve a high cost to cassava production system, making them economically unfeasible.

In contrast, the development of cassava varieties that are tolerant to PPD in the medium and long term is an economically viable strategy. In fact, several studies observed different genotype behaviors for PPD-tolerance (Sánchez et al., 2006; Salcedo et al., 2010; Canto et al., 2013). Wheatley et al. (1985) suggested the PPD severity can be evaluated by a methodology based on the visual quantification of the symptom distribution by means of a scale ( 0 to $100 \%)$. This symptom scale considers the affected perimeter area by PPD. However, recent observations have indicated that many germplasm accessions do not adequately match the distribution of PPD symptoms. The development of a scale to evaluate the severity caused by PPD helps to minimize the estimated subjectivity by the evaluator, in order to avoid disparity in results. Therefore, it is necessary to develop reliable and easy methods to deal with different PPD symptoms occurring in various shapes of parenchyma tissues. In this context, there is a gap in the development of appropriate tools for PPD evaluation and quantification that are easy and quick to use with high accuracy, precision, and reproducibility. Accuracy represents the closeness between the estimated and true severities. Precision refers to the variation or repeatability that is associated with an estimate, and reproducibility refers to the absence of variation in estimates when the same sample is assessed by another evaluator (Nutter Jr. \& Schultz, 1995).

Similar to what occurs with plant diseases, PPD severity can be visually estimated, but it can be subjected to large errors and subjectivity. Furthermore, several strategies have been proposed to minimize the subjectivity of severity estimates, in which the grading scale stands out because it consists of an illustrated representation of biotic or abiotic stress.

The objective of this work was to develop a scale to assess the severity of postharvest physiological deterioration (PPD) of cassava roots, and to validate this scale for accuracy and reproducibility estimates.

\section{Materials and Methods}

For preparing the scale, BRS Formosa cassava roots were collected in the area of Embrapa Mandioca e Fruticultura in Cruz das Almas (BA). Cassava plants were carefully harvested at 11 months to avoid physical damage, and roots were stored in an open shed at room temperature. Roots with $20-30 \mathrm{~cm}$ were cut transversely $(2 \mathrm{~cm})$ every day, up to 20 days, according to the PPD progress, and photographed with a digital camera (Sony SLT A37K DT 18-55mm).

A total of 150 transverse section images of approximately 80 cassava roots with different levels of PPD severity, which were then analyzed using Assess (The American Phytopathological Society, St. Paul, $\mathrm{MN}$, USA), were selected to determine the full area and the injured area of each root transverse section. These data were used as the true values of severity in the linear regression models, using the formula $y=b x+a$, in which: $y$ is the predicted score; $b$ is the slope of the line; and a is the y intercept.

To validate the diagrammatic scale for PPD, 150 cassava cross sections, covering different levels of

Pesq. agropec. bras., Brasília, v.50, n.8, p.658-668, ago. 2015 DOI: $10.1590 / \mathrm{S} 0100-204 X 2015000800004$ 
PPD severity (0 to $100 \%$ ), were used. Disease severity was evaluated by seven evaluators (numbered 1 through 7), four of whom were inexperienced (1 to 4 ), and three were experienced (5 to 7). Initially, the 150 images with different PPD symptoms were evaluated in percentage of PPD severity in the roots, without using the diagrammatic scale. In the second step, the evaluators used the proposed diagrammatic scale to estimate the PPD severity (Figure 1).

The accuracy, which represents the proximity degree between the estimated and actual severity, was evaluated by the intercept (a) and by the angular coefficient of linear regression (b). The closer to zero is the intercept for linear regression (a) and the closer to an angular coefficient (b), the greater is the accuracy of the estimates (Mazaro et al., 2006).
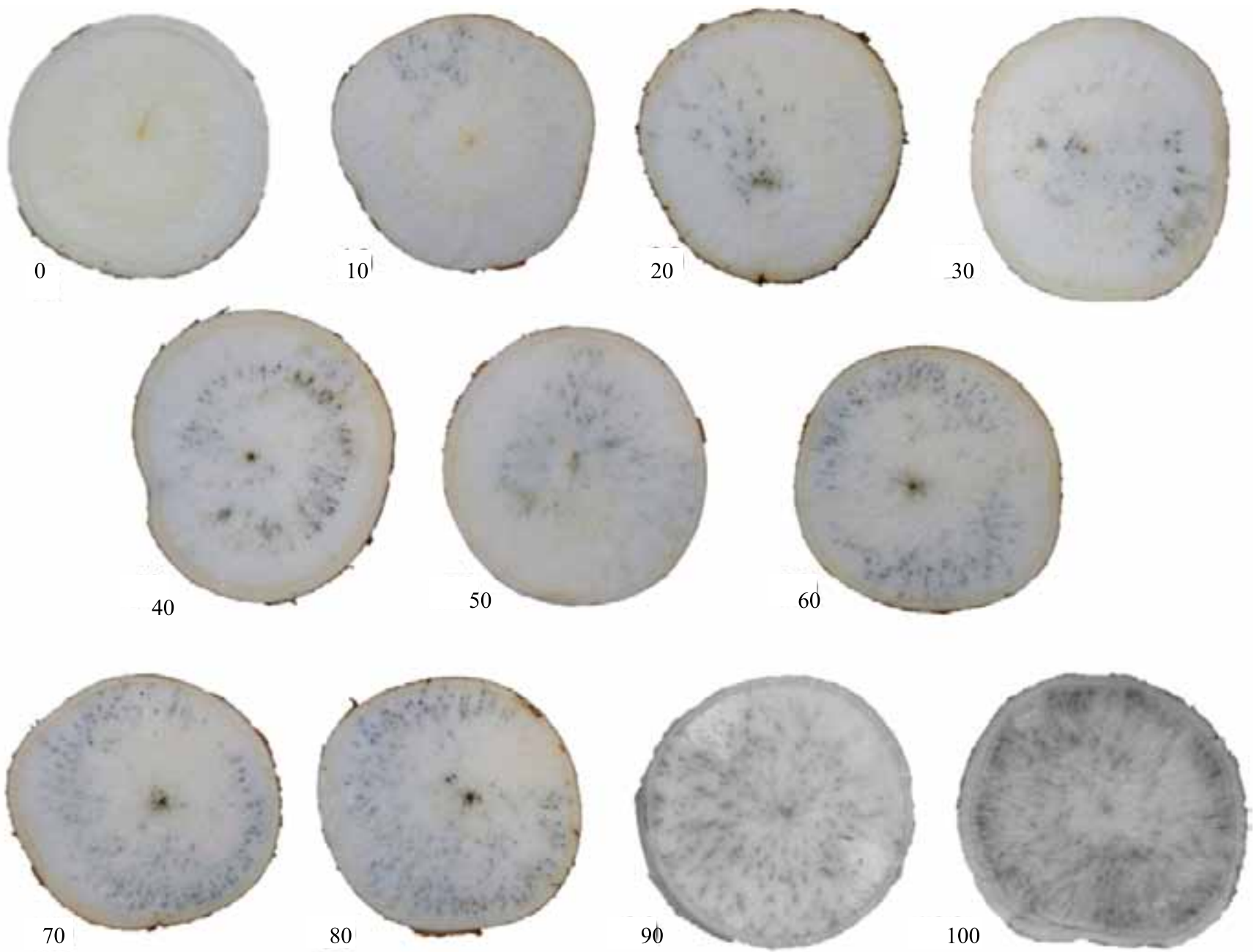

Figure 1. Diagrammatic scale for the severity assessment of physiological deterioration of cassava roots, indicating the levels $0,10,20,30,40,50,60,70,80,90$, and $100 \%$ of the injured area. 


\section{Results and Discussion}

The severity levels as represented by the proposed diagrammatic scale are $0,10,20,30,40,50,60,70$, 80,90 , and $100 \%$ (Figure 1). All the score values were represented on 150 images, which were provided to the evaluators, looking for full representation of the grading scale. Nevertheless, the mean severity of the physiological deterioration was $44 \%$.

In general, the accuracy in the evaluation of PPD symptoms as estimated by $\mathrm{R}^{2}$ was high with or without using the diagrammatic scale (Table 1). Without using the scale, the inexperienced evaluators obtained from 0.76 to 0.86 for $\mathrm{R}^{2}$ values between the real and estimated severity, and the experienced evaluators obtained from 0.90 to 0.96 . The combined average of the evaluators was 0.81 for the inexperienced and 0.93 for the experienced ones, with 0.86 overall average. Moreover, using the grading scale for PPD, the $\mathrm{R}^{2}$ values ranged from 0.87 to 0.92 , between the inexperienced evaluators, and from 0.96 to 0.97 , among experienced evaluators, with 0.93 overall mean.

Using the PPD scale, the evaluators improved the accuracy levels for severity estimates, as observed by other authors who evaluated dendrophama blight in strawberry (Mazaro et al., 2006), gray mold in castor bean (Sussel et al., 2009), and maize white spot (Malagi et al., 2011). Some studies have shown some variability among evaluators using the same scale; therefore, assessments of accuracy and precision are greatly influenced by the ability of each evaluator to estimate the inherent severity (Nutter Jr. \& Schultz, 1995), and can be affected by factors such as the complexity of the severity to be assessed, as for cassava, and as the different types of PPD in their shapes and colors.

Considering the diagrammatic scale validation, the intercept values (a) by all the evaluators without using the scale differed significantly from zero $(\mathrm{p}<0.05)$, indicating that the estimates of PPD severity were overestimated, with the constant presence of positive deviations for all severity levels. Using the rating scale, two evaluators (one experienced and other inexperienced) were more accurate for indicating the severity values caused by PPD (intercept $\mathrm{p}>0.05$ ). Without using the scale, the average intercept value (a) was 9.21 for inexperienced and 5.38 for experienced evaluators. Moreover, using the scale, the average value of the regression intercept (a) between the inexperienced and experienced evaluators was 4.94 and 2.51 , respectively (Table 1 ).

Other studies have reported that $60 \%$ of the evaluators suffered systematic deviations without using the scale, while after using it, this number was reduced by half (Celoto \& Papa, 2010). In another study with yellow passion fruit, four evaluators who did not use the scale (two experienced and two inexperienced) overestimated the severity of anthracnose in the fruit, while after using the scale, only the two inexperienced evaluators continued to show systematic deviations

Table 1. Intercept (a), angular coefficient (b), and coefficient of determination $\left(\mathrm{R}^{2}\right)$ of the linear regression equations, as calculated between the real and estimated severity of the postharvest physiological deterioration in cassava roots, measured by seven evaluators with or without the aid of the rating scale.

\begin{tabular}{|c|c|c|c|c|c|c|}
\hline \multirow[t]{2}{*}{ Evaluator } & \multicolumn{3}{|c|}{ Without rating scale } & \multicolumn{3}{|c|}{ With rating scale } \\
\hline & $\mathrm{a}$ & $\mathrm{b}$ & $\mathrm{R}^{2}$ & $\mathrm{a}$ & $\mathrm{b}$ & $\mathrm{R}^{2}$ \\
\hline \multicolumn{7}{|l|}{ Inexperienced } \\
\hline 1 & $10.37 *$ & $0.93^{\text {ns }}$ & 0.86 & $8.35 *$ & $0.89^{\text {ns }}$ & 0.92 \\
\hline 2 & $5.44^{*}$ & $0.97^{\mathrm{ns}}$ & 0.80 & $1.54^{\mathrm{ns}}$ & $0.99^{\text {ns }}$ & 0.91 \\
\hline 3 & $5.44^{*}$ & $0.84^{\mathrm{ns}}$ & 0.82 & $5.78^{*}$ & $0.95^{\text {ns }}$ & 0.88 \\
\hline 4 & $15.60 *$ & $0.92^{\text {ns }}$ & 0.76 & $4.08 *$ & $1.04^{\mathrm{ns}}$ & 0.87 \\
\hline Average & $9.21 *$ & $0.92^{\text {ns }}$ & 0.81 & 4.94 & 0.97 & 0.90 \\
\hline \multicolumn{7}{|l|}{ Experienced } \\
\hline 5 & $8.62 *$ & $0.96^{\mathrm{ns}}$ & 0.90 & $4.67 *$ & $0.93^{\text {ns }}$ & 0.96 \\
\hline 6 & $3.81 *$ & $0.86^{\text {ns }}$ & 0.92 & $0.87^{\mathrm{ns}}$ & $0.96^{\mathrm{ns}}$ & 0.97 \\
\hline 7 & $3.70^{*}$ & $0.94^{\mathrm{ns}}$ & 0.96 & $2.00 *$ & $0.96^{\mathrm{ns}}$ & 0.97 \\
\hline Average & 5.38 & 0.92 & 0.93 & 2.51 & 0.95 & 0.97 \\
\hline General Average & 7.57 & 0.92 & 0.86 & 3.90 & 0.96 & 0.93 \\
\hline
\end{tabular}

${ }^{n}$ Nonsignificant. *Situation in a null hypothesis $(\mathrm{a}=0$, and $\mathrm{b}=1)$ was rejected by the $\mathrm{t}$ test, at $5 \%$ probability. 
(Fischer et al., 2009). There is a natural tendency to overestimate diseases, taking them for granted by the size and number of lesions, which causes several smaller lesions to have higher scores than the fewer larger ones (Vale et al., 2004). In this case, the score overestimation may be reduced using a diagrammatic scale. Another important aspect is to correct the tendency to overestimate the stress severity by training the evaluators to use the scale (Michereff et al., 2009).

Concerning the angular coefficient values (b), no significant difference $(p<0.05)$ was found among evaluators, regardless of using the grading scale for PPD, which indicates that there were no systematic biases in the deterioration severity estimation. The average value for angular deviation (b) was 0.92 , without the use of scale by both experienced and inexperienced evaluators. However, when using the rating scale, the coefficient $b$ was 0.95 in the observation by experienced evaluators, and 0.97 by inexperienced ones, which indicates a significant reduction of systematic errors in the estimates of severity, and improvement of accuracy (Table 1). Similar results were observed in Isariopsis clavispora in vine (Lenz et al., 2009), target spot in soybean (Soares et al., 2009), and Cercospora spot in pepper (Michereff et al., 2006).

When the evaluation was performed using the rating scale, a significant improvement of the evaluator's accuracy was observed, as the levels of severity were close to the true values obtained by the computer analysis (Figures 2 and 3). Data dispersion on the foreseen and true severity of PPD, without using the diagrammatic scale, reveals a high dispersion of data among the inexperienced raters (S1 to S4), while only the S1 evaluator showed a higher precision of the estimates $\left(\mathrm{R}^{2}=0.86\right)$ (Figure 2$)$. In contrast, when analyzing data dispersion among experienced evaluators (S5 to S7), the S7 evaluator was the most accurate, with the most precise $\mathrm{R}^{2}$ of 0.96 .

Using the PPD scale, a greater precision was achieved by the observations of every evaluator (experienced and inexperienced) than its nonutilization, which can be proved by the highest $\mathrm{R}^{2}$ of $10 \%$ and $7.5 \%$ higher values obtained by inexperienced and experienced evaluators, respectively, in comparison to the nonuse of the scale (Table 1 and Figure 3). Similar works, such as by Aquino et al. (2008), identified an increase of $11 \%$ in precision for the experienced evaluators and of $15 \%$ for the inexperienced ones, when using the scale to assess the Ramularia gossypii in cotton. Similarly, Fischer et al. (2009) observed an increase in the precision of 11 and $22 \%$ by experienced and inexperienced evaluators, respectively, after using the scale to assess anthracnose in passion fruit. It was observed in these studies that using the scale among inexperienced evaluators were more advantageous compared to experienced evaluators. The use of scales to assess disease or physiological problems can guide evaluators for recording data, making the evaluation more precise and accurate. Although it does not replace the evaluator's experience and knowledge of characteristic symptoms of a particular pathogen or physiological stress, the use of scales can also improve the efficiency of both inexperienced and experienced evaluators, thereby providing a reference point for comparison (Aquino et al., 2008).

A reduction of the absolute errors was observed for obtained estimates using the diagrammatic scale, in comparison to the distribution of errors without using the rating scale, as reported by Nascimento et al. (2005), who studied bacterial canker in grapevine, and found that without using the scale, the difference among the waste reached $73.8 \%$, and after using the scale, it remained at $10 \%$. In another pathosystem (anthracnose in Emperor's stick), errors decreased from 25 to $10 \%$ after using the scale (Barguil et al., 2008).

For errors in quantifying the severity, as represented by the differences between the real and estimated values, the distribution of residuals of the evaluations, as performed without a rating scale by inexperienced evaluators, ranged from -70.0 (Figure $4 \mathrm{D}$ ) to 40.0 (Figure $4 \mathrm{C}$ ), and by experienced evaluators, errors ranged from -33.0 (Figure $4 \mathrm{E}$ ) to 35.0 (Figure $4 \mathrm{~F}$ ). Nevertheless, when using the scale, the absolute error by inexperienced evaluators ranged from -35.0 (Figure 5 D) to 35.0 (Figure 5C); and by the experienced evaluators, this variable ranged from -21.0 (Figure $5 \mathrm{E}$ ) to 29.0 (Figure $5 \mathrm{~F}$ ). The average evaluators' errors (in modulus) was 4.04 for the experienced and 2.38 for the inexperienced ones (Figure 5).

Most of the absolute errors were less than $10 \%$, even when the evaluators did not use the scale to estimate the severity, which shows the good precision of the evaluators' estimates. According to Nutter Jr. \& Schultz (1995), values below 10\% in the distribution of absolute errors are considered good for classification in a good grade scale. Using this criterion, only one 

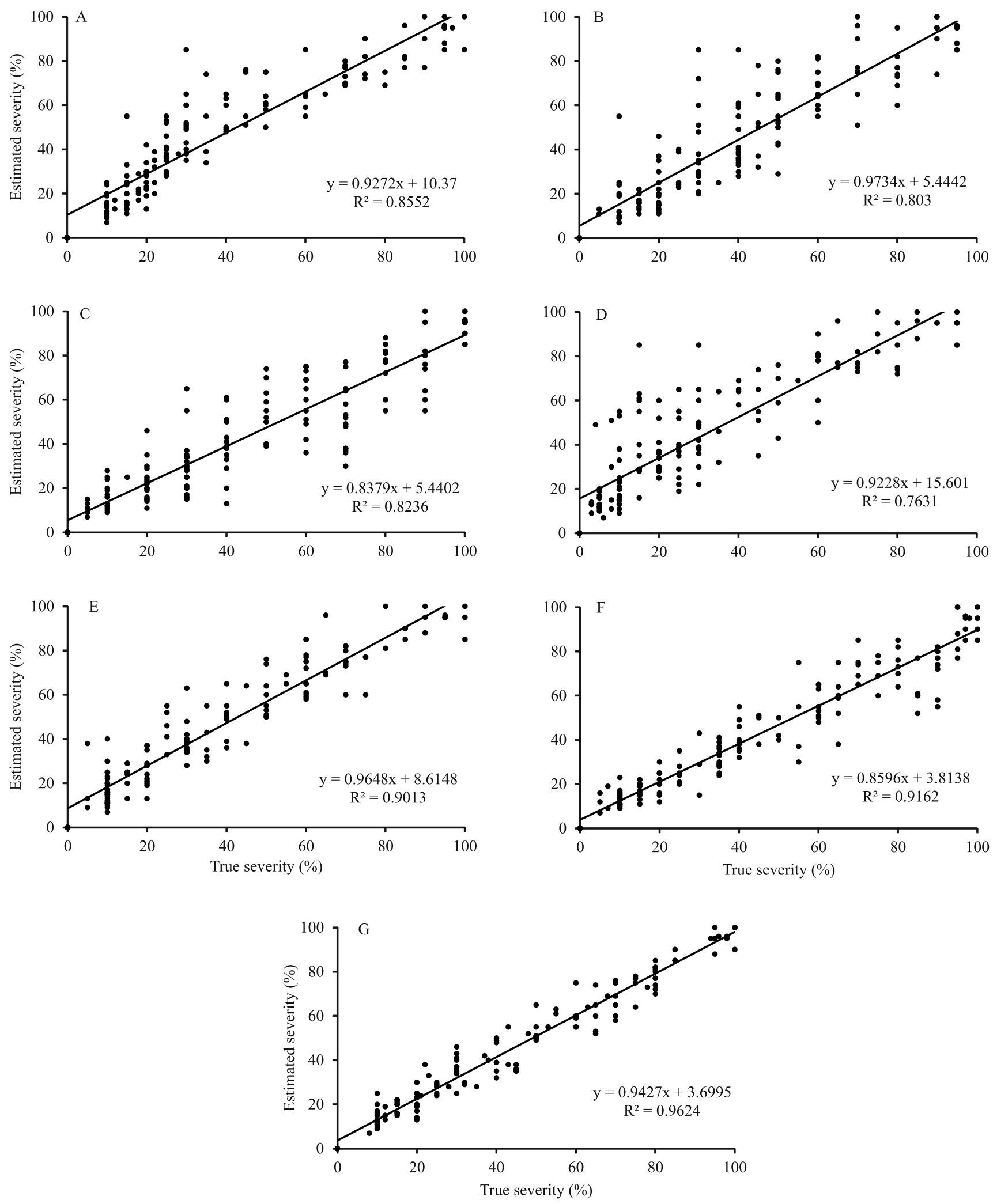

Figure 2. Relationship between the true severity and the estimated severity of the postharvest physiological deterioration in cassava roots, according to estimates by seven evaluators (inexperienced: 1, A; 2, B; 3, C; and 4, D; experienced: 5, E; 6, F; and $7, G$ ) without the aid of diagrammatic scale. 

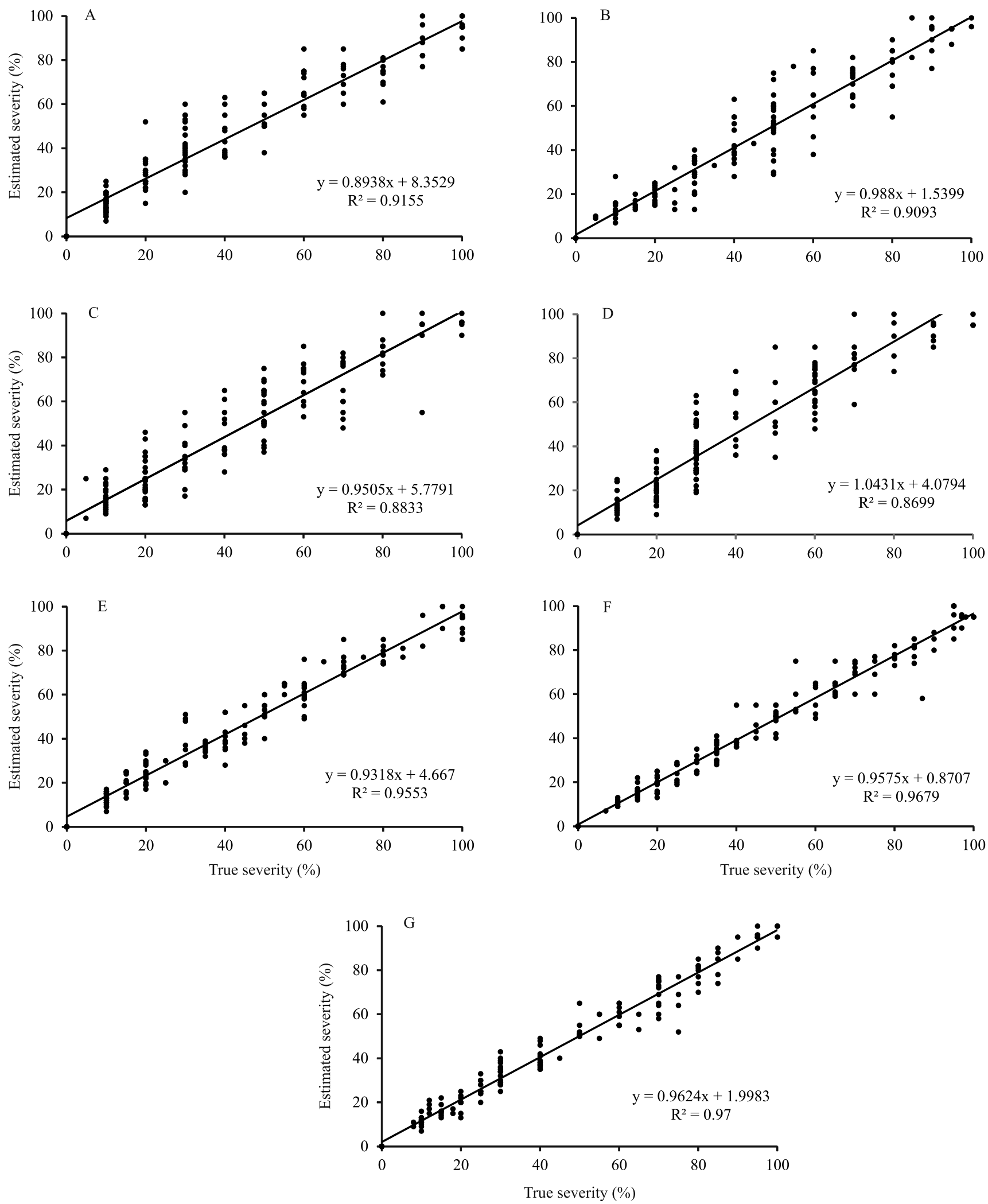

Figure 3. Relationship between the true severity and the estimated severity for the postharvest physiological deterioration in cassava roots, according to estimates by seven evaluators (inexperienced: 1, A; 2, B; 3, C; and 4, D; experienced: 5, E; 6, F; and $7, \mathrm{G}$ ) using the diagrammatic scale. 

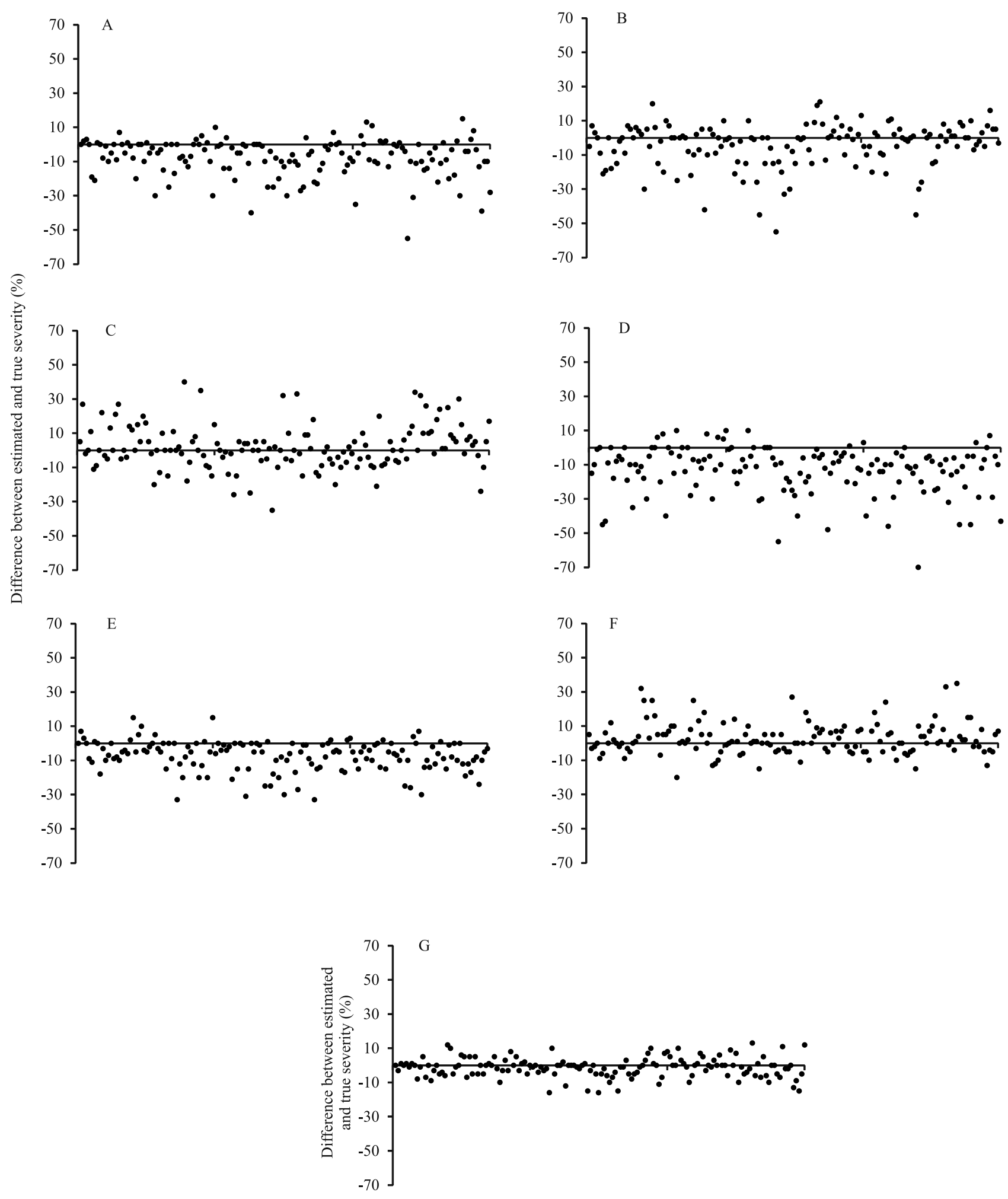

Figure 4. Distribution of the absolute errors (the estimated severity minus the true severity) of severity estimates of the postharvest physiological deterioration in cassava roots, as obtained by seven evaluators (inexperienced: 1, A; 2, B; 3, C; and 4, D; experienced: 5, E; 6, F; and 7, G) without the aid of the diagrammatic scale. 

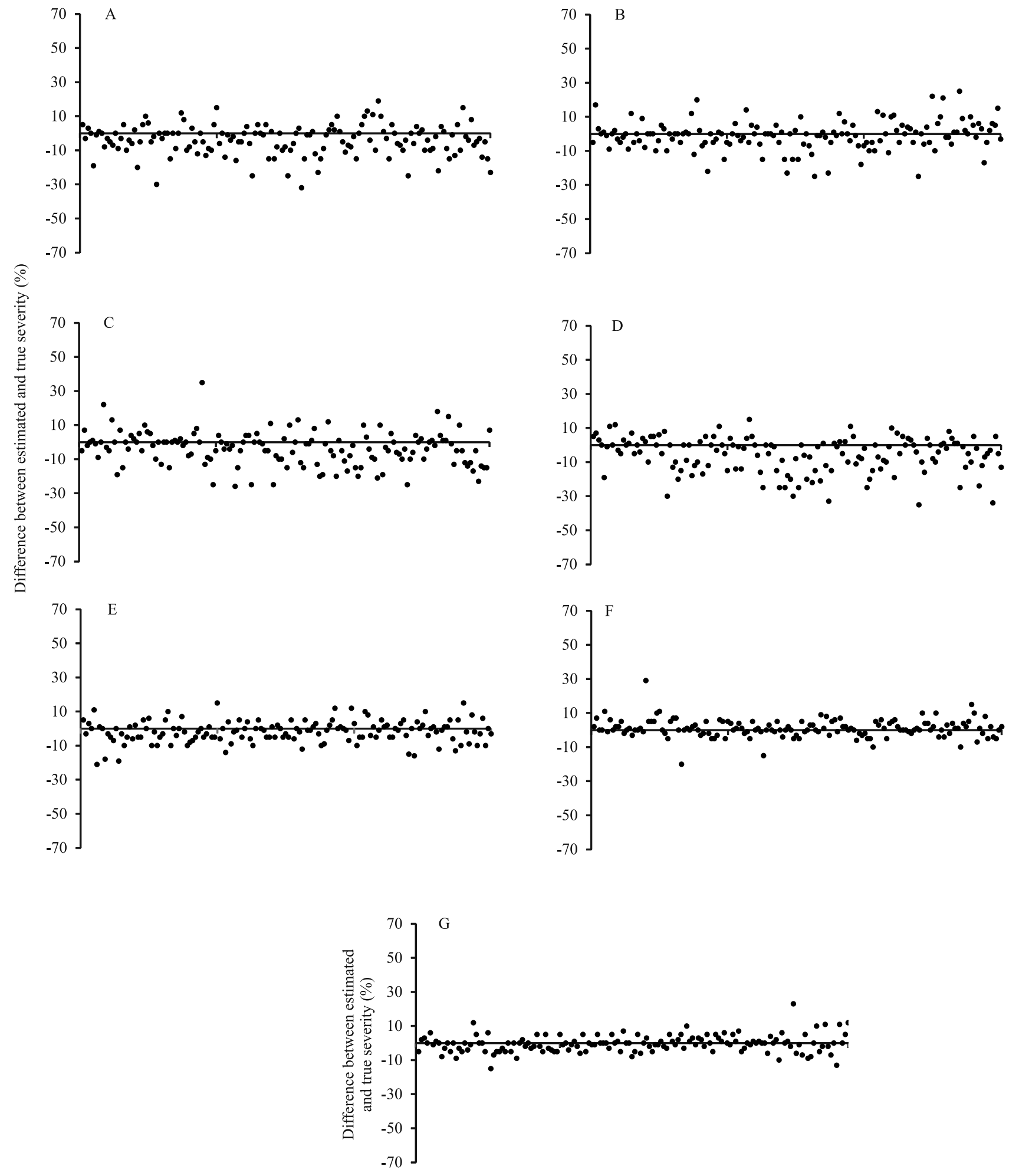

Figure 5. Distribution of the absolute errors (estimated severity minus true severity) of severity estimates of the postharvest physiological deterioration in cassava roots, as obtained by seven evaluators (inexperienced: 1, A; 2, B; 3, C; and 4, D; experienced: $5, \mathrm{E} ; 6$, F; and 7, G) using the diagrammatic scale. 
evaluator (4 - inexperienced) showed absolute errors estimates greater than $10 \%$ (13.23), when the grading scale was not used. However, when the scale was used, the same evaluator showed 5.73 absolute errors, which is less than $10 \%$; therefore, there is a decrease in these errors of approximately $43 \%$ when using the scale. For most of the inexperienced $(1,2$, and 3$)$ and all of the experienced evaluators, using the scale for PPD made it possible to reduce the overall absolute error, compared to the absence of a scale (Figures 4 and 5). The presence of absolute errors, even if minimum, in measurements, is common and can be compensated for by the speed and standardization that a rating scale provides (Stonehouse, 1994).

The reproducibility of the evaluation among the evaluators combined in pairs can also be used as a precision indication of an evaluation method (Nutter Jr. et al., 1993). The determination coefficient $\left(\mathrm{R}^{2}\right)$ of the linear regression equations in comparison with the evaluators' estimates among themselves was lower without using the diagrammatic scale, ranging from 0.61 to 0.91 , and $76 \%$ of the cases were $\geq 0.75$. In contrast, when using the scale, the evaluations of PPD severity had higher determination coefficients $\left(\mathrm{R}^{2}\right)$, which varied from 0.83 to 0.95 and were $\geq 0.75$ in $100 \%$ of the cases, similarly to what was found in the validation of a diagrammatic scale for other pathosystems (Martins et al., 2004; Barbosa et al., 2006) (Table 2).

Regarding the assessment of the severity in pairs without using the scale, the best determination coefficients $\left(\mathrm{R}^{2}\right)$ were observed by experienced evaluators (5:6; 5:7 and 6:7), with $0.86,0.91$, and 0.91 $\mathrm{R}^{2}$, respectively, in comparison to inexperienced raters

Table 2. Coefficient of determination $\left(\mathrm{R}^{2}\right)$ of the linear regression equations relating the estimates of postharvest physiological deterioration of cassava roots among the evaluators, with (below the diagonal) or without (above the diagonal) the aid of the rating scale.

\begin{tabular}{lccccccc}
\hline Evaluator & 1 & 2 & 3 & 4 & 5 & 6 & 7 \\
\hline 1 & - & 0.79 & 0.75 & 0.85 & 0.87 & 0.81 & 0.86 \\
2 & 0.87 & - & 0.74 & 0.74 & 0.80 & 0.78 & 0.79 \\
3 & 0.85 & 0.85 & - & 0.61 & 0.76 & 0.86 & 0.81 \\
4 & 0.89 & 0.83 & 0.83 & - & 0.82 & 0.69 & 0.74 \\
5 & 0.93 & 0.89 & 0.87 & 0.86 & - & 0.86 & 0.91 \\
6 & 0.91 & 0.89 & 0.88 & 0.87 & 0.94 & - & 0.91 \\
7 & 0.89 & 0.90 & 0.88 & 0.84 & 0.94 & 0.95 & - \\
\hline
\end{tabular}

(1:2, 1:3, 1:4, 2:3, 2:4 and 3:4), which showed, in most cases, lower $\mathrm{R}^{2}$ values. The determination coefficient was high in the interaction among experienced evaluators 5,6 , and 7 , without using the scale, whose variation was 0.76 to 0.91 . These values ranged from 0.84 to 0.95 when this scale was used by inexperienced evaluators $(1,2,3$, and 4$)$, who showed $\mathrm{R}^{2}$ values from 0.61 to 0.85 without using the scale, and from 0.83 to 0.89 using the scale.

\section{Conclusion}

The diagrammatic scale proposed to quantify the severity of the cassava physiological deterioration leads to a significant improvement of the accuracy and reproducibility levels of the estimates; therefore, this scale can be used to study deterioration progression and to evaluate their severity in the cassava germplasm.

\section{Acknowledgments}

To Fundação de Amparo à Pesquisa do Estado da Bahia (Fapesb), to Coordenação de Aperfeiçoamento de Pessoal de Nível Superior (Capes), and to Conselho Nacional de Desenvolvimento Científico e Tecnológico (CNPq), for financial support and scholarship grant.

\section{References}

AQUINO, L.A.; BERGER, P.G.; RODRIGUES, F.Á.; ZAMBOLIM, L.; HERNANDEZ, F.R.; MIRANDA, L.M. Elaboração e validação de escala diagramática para quantificação da mancha de ramularia do algodoeiro. Summa Phytopathologica, v.34, p.361-363, 2008. DOI: 10.1590/S0100-54052008000400012.

ARISTIZÁBAL, J.; SÁNCHEZ, T. Guía técnica para producción y análisis de almidón de yuca. Roma: FAO, 2007. 153p. (FAO. Boletín de servicios agrícolas, 163).

BARBOSA, M.A.G.; MICHEREFF, S.J.; MORA-AGUILERA, G. Elaboração e validação de escala diagramática para avaliação da severidade da ferrugem branca do crisântemo. Summa Phytopathologica, v.32, p.57-62, 2006.

BARGUIL, B.M.; ALBERT, I.C.L.; MICHEREFF, S.J.; OLIVEIRA, S.M.A. de. Escala diagramática para avaliação da severidade da antracnose em bastão do imperador. Ciência Rural, v.38, p.807-810, 2008. DOI: 10.1590/S0103-84782008000300034.

CANTO, A.R.; FONSECA JÚNIOR, N. da S.; BELEIA, A. Alterações químicas e histológicas em mandiocas armazenadas das cultivares Catarina Amarela e Catarina Branca. Acta Agronómica, v.62, p.105-113, 2013.

CELOTO, M.I.B.; PAPA, M.F.S. Elaboração e validação de escala diagramática para quantificação da mancha alvo em folhas de 
acerola. Tropical Plant Pathology, v.35, p.258-262, 2010. DOI: $10.1590 /$ S1982-56762010000400010.

CEREDA, M.P.; VILPOUX, O.F. Culture of starchy tubers in Latin America. São Paulo: Fundação Cargill, 2003. 694p. v.3: technology, use and potentialities of Latin-American starchy tubers.

FISCHER, I.H.; ALVES, S.A.M.; ALMEIDA, A.M. de; ARRUDA, M.C. de; BERTANI, R.M. de A.; GARCIA, M.J. de M. Elaboração e validação de escala diagramática para quantificação da severidade da antracnose em frutos de maracujá amarelo. Summa Phytopathologica, v.35, p.226-228, 2009. DOI: 10.1590/ S0100-54052009000300012.

LENZ, G.; COSTA, I.D. da; BALARDIN, R.S.; MARQUES, L.N.; ARRUÉ, A.; STEFANELO, M.S.; ZEMOLIN, C.R. Elaboração e validação de escala diagramática para quantificação da mancha de isariopsis da videira. Ciência Rural, v.39, p.2301-2308, 2009. DOI: $10.1590 / \mathrm{S} 0103-84782009000800005$.

MALAGI, G.; SANTOS, I. dos; CAMOCHENA, R.C.; MOCCELLIN, R. Elaboração e validação da escala diagramática para avaliação da mancha branca do milho. Revista Ciência Agronômica, v.42, p.797-804, 2011. DOI: 10.1590/ S1806-66902011000300028.

MARTINS, M.C.; GUERZONI, R.A.; CÂMARA, G.M. de S.; MATTIAZZI, P.; LOURENÇO, S.A.; AMORIM, L. Escala diagramática para a quantificação do complexo de doenças foliares de final de ciclo em soja. Fitopatologia Brasileira, v.29, p.179-184, 2004. DOI: 10.1590/S0100-41582004000200009.

MAZARO, S.M.; DE GOUVEA, A.; MAY DE MIO, L.L.; DESCHAMPS, C.; BIASI, L.A.; CITADIN, I. Escala diagramática para avaliação da severidade da mancha-de-dendrophoma em morangueiro. Ciência Rural, v.36, p.1630-1633, 2006. DOI: 10.1590/S0103-84782006000200045.

MICHEREFF, S.J.; NORONHA, M. de A.; ANDRADE, D.E.G.T. de; OLIVEIRA, E.P. de; XAVIER FILHA, M.S.; MOREIRA, P.A.A. Elaboração e validação de escala diagramática para a cercosporiose do pimentão. Summa Phytopathologica, v.32, p.260-266, 2006. DOI: 10.1590/S0100-54052006000100007.

MICHEREFF, S.J.; NORONHA, M.A.; LIMA, G.S.A.; ALBERT, I.C.L.; MELO, E.A.; GUSMÃO, L.O. Diagrammatic scale to assess downy mildew severity in melon. Horticultura Brasileira, v.27, p.76-79, 2009. DOI: 10.1590/S0102-05362009000100015.

MORANTE, N.; SANCHEZ, T.; CEBALlOS, H.; CALlE, F.; PEREZ, J.C.; EGESI, C.; CUAMBE, C.E.; ESCOBAR, A.F.; ORTIZ,D.; CHAVEZ,A.L.; FREGENE, M. Tolerance to postharvest physiological deterioration in cassava roots. Crop Science, v.50, p.1333-1338, 2010. DOI: 10.2135/cropsci2009.11.0666.

NASCIMENTO, A.R.P.; MICHEREFF, S.J.; MARIANO, R. de L.R.; GOMES, A.M.A. Elaboração e validação da escala diagramática do cancro bacteriano da videira. Summa Phytopathologica, v.31, p.59-64, 2005.

NUTTER JR., F.W.; GLEASON, M.L.; JENCO, J.H.; CHRISTIANS, N.C. Assessing the accuracy, intra-rater repeatability, and inter-rater reliability of disease assessment systems. Phytopathology, v.83, p.806-812, 1993. DOI: 10.1094/ Phyto-83-806.

NUTTER JR., F.W.; SCHULTZ, P.M. Improving the accuracy and precision of disease assessments: selection of methods and use of computer-aided training programs. Canadian Journal of Plant Pathology, v.17, p.174-184, 1995. DOI: 10.1080/07060669509500709.

SALCEDO, A.; DEL VALLE, A.; SANCHEZ, B.; OCASIO, V.; ORTIZ, A.; MARQUEZ, P.; SIRITUNGA, D. Comparative evaluation of physiological post-harvest root deterioration of 25 cassava (Manihot esculenta) accessions: visual vs. hydroxycoumarins fluorescent accumulation analysis. African Journal of Agricultural Research, v.5, p.3138-3144, 2010.

SALCEDO, A.; SIRITUNGA, D. Insights into the physiological, biochemical and molecular basis of postharvest deterioration in cassava (Manihot esculenta) roots. American Journal of Experimental Agriculture, v.1, p.414-431, 2011. DOI: 10.9734/ AJEA/2011/784.

SÁNCHEZ, T.; CHÁVEZ, A.L.; CEBALlOS, H.; RODRIGUES-AMAYA, D.B.; NESTEL, P.; ISHITANI, M. Reduction or delay of post-harvest physiological deterioration in cassava roots with higher carotenoid content. Journal of the Science of Food and Food Agriculture, v.86, p.634-639, 2006. DOI: 10.1002 jsfa.2371.

SOARES, R.M.; GODOY, C.V.; OLIVEIRA, M.C.N. de. Escala diagramática para avaliação da severidade da mancha alvo da soja. Tropical Plant Pathology, v.34, p.333-338, 2009. DOI: 10.1590/ S1982-56762009000500007.

STONEHOUSE, J. Assessment of Andean bean diseases using visual keys. Plant Pathology, v.43, p.519-527, 1994. DOI: 10.1111/j.1365-3059.1994.tb01586.x.

SUSSEL, A.A.B.; POZZA, E.A.; CASTRO, H.A. Elaboração e validação de escala diagramática para avaliação da severidade do mofo cinzento em mamoneira. Tropical Plant Pathology, v.34, p.186-191, 2009. DOI: 10.1590/S1982-56762009000300010.

VALE, F.X.R. do; JESUS JÚNIOR, W.C. de; LIBERATO, J.R.; SOUZA, C.A. Quantificação de doenças e do crescimento do hospedeiro. In: VALE, F.X.R.; JESUS JUNIOR, W.C.; ZAMBOLIN, L. (Ed.). Epidemiologia aplicada ao manejo de doenças de plantas. Belo Horizonte: Perfil, 2004. p.91-121.

WHEATleY, C.; LOZANGO, C.; GOMEZ, G. Post-harvest deterioration of cassava roots. In: COCK, J.H.; REYES, J.A. (Ed.). Cassava: research, production and utilization. Cali: UNDP-CIAT, 1985. p.655-671.

ZIDENGA, T.; LEYVA-GUERRERO, E.; MOON, H.K.; SIRITUNGA, D.; SAYRE, R. Extending cassava root shelf life via reduction of reactive oxygen species production. Plant Physiology, v.159, p.1396-1407, 2012. DOI: 10.1104/pp.112.200345.

Received on October 21, 2014 and accepted on June 10, 2015

Pesq. agropec. bras., Brasília, v.50, n.8, p.658-668, ago. 2015

DOI: $10.1590 / \mathrm{S} 0100-204 X 2015000800004$ 